\title{
MERETAS PERAN GANDA ISTRI NELAYAN DALAM HOUSEHOLD ECONOMY EMPOWERMENT
}

\author{
Bayu Tri Cahya, Muhammad Soni Salahuddin, Jadzil Baihaqi \\ IAIN Kudus, Indonesia \\ E-mail: cahyab380@gmail.com
}

\begin{abstract}
Demak Regency has a coastal area which is one of the livelihoods of fishermen, namely Kampung Rajungan Demak. A part of social potential in Coastal society is women especially fishermen wives. Coastal women has an important role at fishing households. Wives should only be responsible for the domestic sector, but this developes when women fisherman play a role to looking for a living. The involvement of the women fisherman in earning a living creates a double rol in the household. This research assesses the dual role of woman fisheman in the household economy. This research was conducted in Betahwalang Village, Bonang District, Demak Regency. The purpose of this study is to reveal the dual role of women fisherman in empowering the household economy. This research used qualitaive data analysis method with interview, observation and documentation data collection techniques. The results of this research showed that the double role of women fisherman provides a significant contribution in improving the household economy.
\end{abstract}

Keywords: double role; women fisherman; household economy

\begin{abstract}
Abstrak. Kabupaten Demak memiliki wilayah pesisir yang menjadi salah satu sumber mata pencaharian para nelayan yakni Kampung Rajungan Demak. Salah satu komponen potensi sosial dalam masyarakat pesisir adalah kaum perempuan khususnya istri nelayan. Perempuan pesisir memiliki peran penting dalam rumah tangga nelayan. Seyogyanya istri hanya bertanggung jawab pada sektor domestik, namun hal tersebut berkembang apabila kaum istri ikut berperan dalam mencari nafkah. Keterlibatan istri dalam mencari nafkah menimbulkan peran ganda di dalam rumah tangga. Penelitian ini menggambarkan peran ganda istri nelayan dalam ekonomi rumah tangga. Penelitian ini dilakukan di Desa Betahwalang Kecamatan Bonang Kabupaten Demak. Tujuan kajian artikel ini adalah mengungkap peran ganda istri nelayan dalam penguatan ekonomi rumah tangga. Metode analisa data yang digunakan adalah metode kualitatif dengan teknik pengumpulan data wawancara, observasi dan dokumentasi. Dari hasil penelitian tersebut menggambarkan bahwa peran ganda istri nelayan memberikan kontribusi yang signifikan dalam penguatan ekonomi rumah tangga.
\end{abstract}

Kata Kunci: peran ganda; istri nelayan; ekonomi rumah tangga

Permalink/DOI: https://doi.org/10.15408/harkat.v15i1.13001 


\section{Pendahuluan}

Indonesia merupakan salah satu negara maritim(http://scdc.binus.ac.id/himpgsd/2017/0 9/negara-maritim/ diakses pada 2019). 2/3 wilayah Indonesia merupakan perairan yakni dengan luas wilayah perairan $6.315 .222 \mathrm{Km}^{2}$ dengan panjang garis pantai $99.093 \mathrm{Km}^{2}$ serta jumlah pulau 13.466 pulau yang bernama dan berkoordinat (http://big.go.id/beritasurta/show /pentingnya-informasi-geospasial-untuk-menatalaut-indonesia/ diakses pada 2018). Dengan kekuatan tersebut, Indonesia memiliki potensi besar untuk memajukan perekonomian Indonesia yakni salah satunya melalui sektor perikanan. Dari data Food and Agriculture Organization (FAO) pada tahun 2012, Indonesia menempati peringkat ke-tiga terbesar dunia dalam produksi perikanan dibawah China dan India (http://www.fao.org/3/a-i2727e.pdf/ diakses pada 2018).

Menurut data dari Departemen Kelautan dan Perikanan Indonesia, setiap tahun sektor perikanan mampu meningkatkan sumbangannya terhadap pendapatan Negara bukan pajak (PNBP) (Suci Sedya Utami, 2018). Kehidupan pesisir Indonesia seharusnya menjadikan para nelayan sebagai orang yang kaya karena kekayaan laut Indonesia yang melimpah. Namun kenyataannya, mereka masih berada dalam keadaan yang memprihatinkan bahkan masih banyak masyarakat yang berada di bawah garis kemiskinan (Diana Djuwita, 2015).

Sebagian besar nelayan di Indonesia dikategorikan sebagai nelayan tradisional dan nelayan buruh. Pada nelayan tradisional, pengaruh musim yang ada di wilayah pesisir sangat mempengaruhi hasil tangkapan, sehingga mempengaruhi kondisi ekonomi keluarga nelayan pula. Hal ini disebabkan karena alat tangkap yang digunakan oleh nelayan masih tradisional sehingga nelayan terhambat dalam meningkatkan kesejahteraan sosial dan mengatasi kemiskinan (Ahmad Nurholis, 2016). Dengan demikian, pengaruh musim akan memperpanjang musim peceklik nelayan dan membuat kondisi ekonomi keluarga semakin memburuk. Saat nelayan tidak melaut karena cuaca buruk, sementara kebutuhan hidup tetap harus dipenuhi maka mereka memilih untuk berhutang.

Salah satu komponen potensi sosial dalam masyarakat nelayan adalah kaum perempuan pesisir, khususnya istri nelayan. Istri nelayan adalah istri yang hidup di lingkungan keluarga nelayan dengan aktivitas mencari nafkah di luar kehidupan sebagai nelayan. Kedudukan dan peranan kaum istri nelayan sangat penting karena merupakan bagian dalam sistem pembagian kerja secara seksual pada masyarakat pesisir khususnya nelayan (Handayani dan Endang Gunaisah, 2012).

Terdapat pembagian kerja antara ayah dan ibu, ayah memiliki areal pekerja publik karena kedudukannya sebagai pencari nafkah utama di dalam keluarga, sedangkan ibu memiliki areal pekerja domestik yang dapat diartikan oleh sebagian masyarakat yang menyatakan bahwa seorang ibu hanya sekedar perempuan yang memiliki tiga fungsi yaitu, memasak, melahirkan anak, dan berhias (Muhammad Washfi, 2005). Secara fitrah, seorang istri telah dibebankan untuk hamil dan melahirkan, tugas itu sudah sangat berat, bagaimana jika tugas itu harus lebih dibebankan lagi dengan mencari nafkah. Oleh karena itu, Islam cukup membebankan nafkah hanya bagi suami. (Hasbiallah, 2015).

Kaum istri di desa-desa nelayan mengambil kedudukan dan peranan sosial yang penting, baik sektor domestik maupun di sektor publik. Peranan publik istri nelayan diartikan sebagai keterlibatan kaum istri dalam aktivitas sosial ekonomi di lingkungan dalam rangka memenuhi kebutuhan hidup rumah tangga dan kebutuhan sekunder lainnya. Kaum istri di desa nelayan merupakan potensi sosial yang sangat strategis untuk mendukung kelangsungan hidup masyarakat nelayan secara keseluruhan. Oleh karena itu, potensi sosial ekonomi kaum istri 
sangat penting yang berperan sebagai ibu rumah tangga, sehingga tidak bisa diabaikan begitu saja (Kusnadi, Hari Sulistiyowati, Sumarjono, Adi Prasodjo, 2006).

Keberhasilan suatu keluarga dalam membentuk rumah tangga yang sejahtera tidak lepas dari peran seorang perempuan (istri). Pada keluarga yang tingkat perekonomiannya kurang atau pra-sejahtera peran wanita tidak hanya dalam areal pekerjaan domestik tetapi juga areal publik. Ini dimungkinkan terjadi karena penghasilan sang suami sebagai pencari nafkah utama tidak dapat mencukupi kebutuhan keluarga (Arsini, 2014). Para kaum perempuan lebih banyak melakukan pekerjaan-pekerjaan yang bersifat informal seperti berdagang, menjadi pembantu rumah tangga dan lain sebagainya dalam upaya mencari nafkah tambahan bagi keluarga. Dalam keluarga nelayan peran wanita dapat dilibatkan dalam kegiatan ekonomi produktif. Bentuk-bentuk ekonomi produktif tersebut dapat berupa usaha pengolahan pangan ikan seperti ikan asin, krupuk, dll., pemasaran ikan, serta usaha jasa yang mendukung seperti penyediaan sarana produksi lainnya. Dengan demikian, dalam menghadapi kerentanan ekonomi dan kemiskinan masyarakat nelayan, pihak yang terbebani dan bertanggung jawab untuk mengatasi dan menjaga kelangsungan hidup rumah tangga adalah kaum perempuan atau istri nelayan (Kusnadi, Hari Sulistiyowati, Sumarjono, Adi Prasodjo, 2006).

Adanya wanita bekerja, tentu akan dapat mengangkat kesejahteraan keluarga karena mendapat tambahan penghasilan dari hasil kerja mereka. Dengan adanya tambahan penghasilan istri tingkat pemenuhan kebutuhan menjadi meningkat dan kestabilan sirkulasi ekonomi rumah tangga terjaga. Dengan demikian istri berperan sebagai penguat ekonomi rumah tangga nelayan. Fenomena tersebut menunjukkan peran wanita sebagai ibu rumah tangga dan sebagai pencari tambahan pendapatan bisa berjalan dengan baik karena partisipasi kaum wanita dalam membantu meningkatkan kesejahteraan rumah tangga.

Begitu juga yang terjadi pada istri nelayan yang ada di Desa Betahwalang Kecamatan Bonang Kabupaten Demak. Ibu rumah tangga yang memiliki peran ganda dalam penguatan ekonomi rumah tangga dengan menjadi wanita pekerja.

Penelitian ini dilakukan untuk menganalisa peran ganda istri nelayan dalam penguatan ekonomi rumah tangga. Belum ada yang mengkaji lebih khusus peran ganda istri dalam penguatan ekonomi rumah tangga dan penelitian tentang peran ganda perempuan dalam bidang Ekonomi di Kabupaten Demak masih belum banyak dilakukan, sehingga perlu untuk dikaji dan dilakukan penelitian.

\section{Tinjauan Pustaka}

\section{Kesetaraan Gender di Bidang Ekonomi}

Istilah gender sudah tidak asing lagi dan sering kita dengar. Namun, orang awam memahami gender diidentikkan dengan jenis kelamin (sex). Padalah istilah gender dan jenis kelamin (sex) mengandung makna yang berbeda (Marzuki, 2008). Istilah gender berasal dari bahasa latin genus yang berarti ras, turunan, golongan, atau kelas. Meskipun gender merupakan bentukan sosial dan kultural untuk laki-laki dan perempuan, gender itu lebih untuk kalangan antropologis (Rian Nugroho, 2008).

Kesetaraan gender adalah kesamaan dan keseibangan kondisi antara laki-laki dan perempuan untuk memperoleh kesempatan dan hak-haknya sebagai manusia agar mampu berperan dan berpartisipasi di berbagai bidang (Permari, 2017).

Kesetaraan gender berarti perempuan dan laki-laki memiliki kondisi dan potensi yang sama untuk berkontribusi pada pembangunan nasional dan merealisasikan hak-haknya sebagai manusia. Wujud dari kesetaraan gender adalah 
tidak adanya diskriminasi antara perempuan dan laki-laki dalam kesempatan berpartisipasi, memperoleh akses dan merasakan manfaat dari pembangunan nasional khusunya di bidang ekonomi

(http://m.katadata.co.id/berita/2018/07/06/keset araan-gender-kunci-pertumbuhanekonomi diakses pada 2018).

Ketimpangan gender di Indonesia dapat dilihat sebgai potensi besar kontribusi perempuan terhadap pertumbuhan ekonomi yang belum tergali. Potensi ini dapat digali melalui usaha-usaha mewujudkan kesetaraan gender di sektor ekonomi (http://m.katadata.co.id/berita/2018/07/06/keset araan-gender-kunci-pertumbuhanekonomi diakses pada 2018).

Di dalam peraturan perundang-undangan Negara Kesatuan Republik Indonesia kesetaraan pekerja perempuan di bidang ekonomi diatur dalam Undang-Undang Republik Indonesia Nomor 13 tahun 2003 tentang ketenagakerjaan. Pada bab III (tiga) berisi kesempatan dan perlakuan yang sama. Pada pasal 5 (lima) menyebutkan setiap tenaga kerja memiliki kesempatan yang sama tanpa diskriminasi untuk memperoleh pekerjaan. Pada pasal 6 (enam) menyebutkan setiap pekerja/buruh berhak memperoleh perlakuan yang sama tanpa diskriminasi dari pengusaha (UU RI, 13 Tahun 2003, Ketenagakerjaan).

Dari peraturan tersebut dapat dipahami bahwa kaum perempuan juga mendapatkan akses dan kesempatan yang sama untuk mendapatkan pekerjaan di semua bidang. Itu artinya perempuan memiliki kesempatan dan akses yang sama di bidang ekonomi, meskipun pada kenyataannya masih ada kesenjangan ataupun deskriminasi terhadap kaum perempuan.

\section{Double Role (Peran Ganda) Perempuan}

Peran berarti laku, bertindak. Di dalam Kamus Besar Bahasa Indonesia peran ialah perangkat tingkah laku yang diharapkan dimiliki oleh orang yang berkedudukan di masyarakat (Kamus Besar Bahasa Indonesia, 1995). Peran merupakan aspek dinamis kedudukan (status) yang dimiliki oleh seseorang, apabila seseorang melakukan hak-hak dan kewajiban-kewajibannya sesuai dengan kedudukannya, maka ia menjalankan suatu peranan (Soerjono, 1997).

Peran ganda adalah dua peran atau lebih yang dijalankan dalam waktu yang bersamaan, dalam hal ini peran yang dimaksud adalah peran seorang perempuan sebagai istri bagi suaminya, ibu bagi anak-anaknya, dan peran sebagai perempuan yang memiliki karir di luar rumah. Peran ganda ini dijalani bersamaan dengan peran kaum perempuan sebagai istri dan ibu dalam keluarga, seperti menjadi mitra suami dalam membina rumah tangga, serta mengasuh dan mendidik anak-anak (Stevin M. E. Tumbage, Femmy C. M. Tasik, dan Selvi M. Tumengkol, 2017).

Peran ganda disebutkan dengan konsep dualisme kultural, yakni adanya konsep lingkungan domestik (domestic sphere) dan lingkungan publik (public sphere). Kedua pengertian ini menggambarkan keterpisahan peranan dan pembagian pekerjaan yang ketat antara laki-laki dan perempuan dalam masyarakat yakni peranan kaum perempuan umumnya terbatas pada lingkungan domestik saja (lingkungan khas bagi perempuan) dan lakilaki umumnya dominan pada lingkungan publik (lingkungan khas bagi kaum laki-laki) (Stevin M. E. Tumbage, Femmy C. M. Tasik, dan Selvi M. Tumengkol, 2017).

Dalam rumah tangga, perempuan mempunyai peranan dan kedudukannya baik sebagai istri, ibu, pekerja maupun anggota masyarakat di mana ia tinggal. Pelaku penting dalam dinamika rumah tangga adalah 
perempuan dalam artian perempuan menguasai pengelolaan keuangan, redistribusi pendapatan, dan alokasi konsumsi (Dede Mulyanto, 2006).

Salah satu unsur potensi sosial adalah kaum perempuan khususnya istri nelayan. Kontribusi kaum istri sangat penting karena merupakan bagian dalam sistem pembagian kerja secara seksual pada masyarakat nelayan (Ferdhi $\mathrm{H}, 2006$ ). Istri nelayan mengambil peran publik sebagai manifestasi dari tanggung jawab mereka menjaga kelangsungan hidup rumah tangganya. Pengaturan aktivitas domestik dan publik secara serasi memberikan kontribusi pada istri nelayan untuk memainkan peran yang optimal dalam kedudukannya sebagai istri, ibu anak-anak, dan tiang ekonomi rumah tangga (Kusnadi, Hari Sulistiyowati, Sumarjono, Adi Prasodjo,2006). Oleh sebab itu, kaum perempuan merupakan potensi sumberdaya manusia yang dapat didayagunakan sebagai subjek pemberdayaan dan pembangunan masyarakat pesisir (Kusnadi, 2015).

\section{Konsep Ekonomi Keluarga}

\section{a. Pengertian Ekonomi Keluarga}

Istilah keluarga (families) dan rumah tangga (household) cukup sulit untuk dibedakan. Pernyataan berikut akan menjelaskan bagaimana perbedaan antara keduanya. Rumah tangga adalah mereka yang tinggal bersama, menggunakan sumber daya kolektif untuk mencapai tujuan bersama-sama. Sedangkan keluarga adalah orang-orang yang memiliki ikatan sosial-biologis melalui pernikahan, kelahiran atau adopsi, tidak harus hidup bersama, dan menggunakan sumber daya secara bersama-sama (secara kolektif) untuk mencapai tujuan bersama (Shinta Doriza, 2015).

Ekonomi keluarga merupakan upaya dalam memenuhi kebutuhan hidup melalui aktivitas-aktivitas yang dilakukan oleh sebuah keluarga dalam hal ini khususnya seorang istri, agar dapat memenuhi kebutuhan primer dan sekundar bagi kehidupan sehari-hari (Mirna, 2016).

Dalam Ekonomi rumah tangga, sumber daya dibagi menjadi dua jenis yaitu sumber daya fisik dan sumber daya manusia. Sumber daya alam dan finansial masing-masing sebagai kategori sendiri. Dalam Ekonomi rumah tangga, sumber daya alam dan sumber daya finansial termasuk dalam kategori sumber daya fisik (Shinta Doriza, 2015).

\section{b. Kemiskinan Keluarga Nelayan}

Kemiskinan ialah ketidakmampuan untuk memenuhi standar hidup minimum (Mudrajad Kuncoro, 2006). Secara umum dapat dikatakan bahwa istilah kemiskinan selalu menunjuk pada sebuah kondisi yang serba kekurangan. Dalam kaitan itu, kondisi serba kekurangan itu bisa saja diukur secara obyektif, dirasakan secara subyektif, atau secara relatif didasarkan pada perbandingan dengan orang lain, sehingga melahirkan pandangan obyektif, subyektif dan relatif tentang kemiskinan (Masyhuri Imron, 2003).

Kemiskinan memiliki banyak definisi, dan sebagian besar sering mengaitkan konsep kemiskinan dengan aspek ekonomi. Berbagai upaya untuk mendefinisikan kemiskinan dan mengidentifikasikan kemiskinan sebenarnya menghasilkan suatu konsep pemikiran yang dapat disederhanakan. kemiskinan dibedakan menjadi dua yaitu kemiskinan absolut dan relatif. Seseorang dikatakan miskin secara absolut apabila pendapatannya lebih rendah dari garis kemiskinan absolut atau dengan istilah lain jumlah pendapatannya tidak cukup untuk memenuhi kebutuhan hidup minimum (Nunung Nurwati, 2008). Kemiskinan relatif adalah keadaan perbandingan antara kelompok pendapatan dalam masyarakat, yaitu antara kelompok yang mungkin tidak miskin karena mempunyai tingkat pendapatan yang lebih tinggi dari garis kemiskinan, dan kelompok 
masyarakat yang relatif lebih kaya (Nunung Nurwati, 2008).

Masyarakat nelayan merupakan masyarakat yang identik dengan masyarakat miskin, dari berbagai uraian di atas bahwa masyarakat nelayan tergolong pada kemisinan absolut dimana pendapatan mereka setiap harinya tidak menentu kadang untung kadang rugi, sehingga kadang dalam rumah tangga nelayan sering mengalami kekurangan dalam pemenuhan kebutuhan pokok keluarga. Hal tersebut dikarenakan para nelayan hanya menggantungkan hidupnya pada hasil laut selain itu sifat ketergantungan masyarakat kepada pemilik modal masih tinggi (Subaidi, 2015).

c. Pemberdayaan Ekonomi Rumah tangga

Pemberdayaan berasal dari kata "daya" yang artinya kekuatan. Jika dalam bahasa Inggris "empowerment" yang secara harfiyah bisa diartikan sebagai pemberkuasaan, dalam arti pemberian atau peningkatan keberkuasaan atau power (Harry Hikmat, 2004). Jadi pemberdayaan adalah penguatan yaitu penguatan yang lemah. Dalam hal ini, pemberdayaan yang maksud yaitu penguatan terhadap ekonomi rumah tangga yang masih lemah.

Pemberdayaan ekonomi keluarga merupakan suatu proses atau kegiatan agar keluarga mampu melakukan kegiatan ekonomi (bekerja atau berusaha) yang merupakan salah satu unsur kesejahteraan keluarga (Hardinsyah dan Ujang Sumarwan, 1997). Dari proses ini diharapkan tujuan pemberdayaan ekonomi berupa peningkatan pendapatan dan kesejahteraan bagi keluarga dilakukan dengan meningkatkan usaha yang ada maupun menciptakan kesempatan kerja baru serta meningkatkan daya tawar mereka melalui pendampingan partisipatif dan berkelanjutan (Dewi Cahyani Puspitasari, 2012).

\section{Kerangka Berpikir}

Kerangka berfikir digunakan sebagai acuan agar peneliti memiliki arah penelitian yang sesuai dengan tujuan penelitian. Adapun kerangka berfikir pada penelitian kali ini secara sitematis

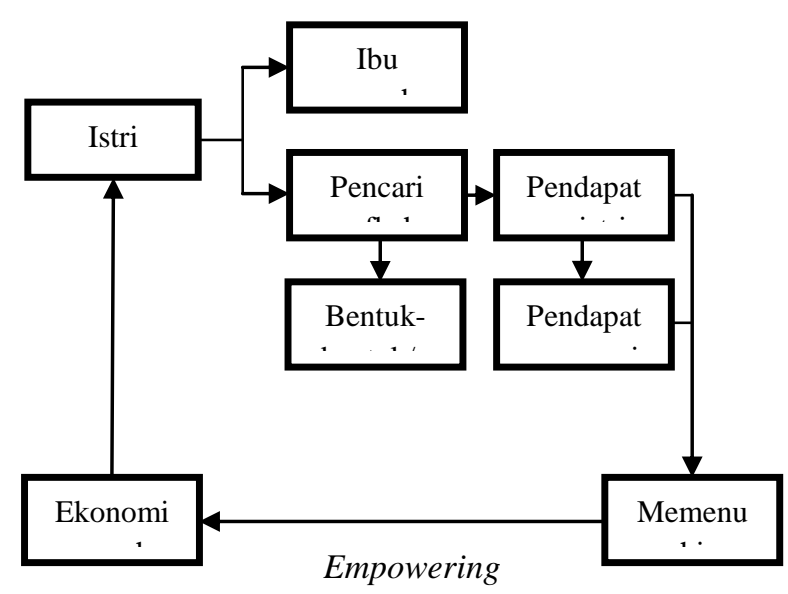

disajikan sebagai berikut:

\section{Metode Penelitian}

Penelitian ini menggunakan metode penelitian kualitatif. Metode penelitian kualitatif adalah metode penelitian yang berlandaskan pada filsafat postpositivisme, digunakan untuk meneliti pada kondisi obyek yang alamiah (natural setting), di mana peneliti adalah sebagai instrumen kunci, tehnik pengumpulan data secara triangulasi (gabungan), analisis data bersifat induktif/kualitatif, dan hasil penelitian kualitatif lebih menekankan makna dari pada generalisasi (Sugiyono, 2011).

Penelitian ini merupakan penelitian yang tergolong penelitian lapangan (field research) yang bertujuan untuk mempelajari secara intensif latar belakang, status akhir, interaksi lingkungan yang terjadi pada suatu satuan sosial seperti individu, kelompok, lembaga, atau komunitas (Saifuddin Azwar, 2004). Oleh karena itu, obyek penelitiannya adalah obyek di lapangan yang sekiranya mampu memberikan informasi mengenai kajian penelitian. Dalam hal ini, peneliti mengumpulkan data dari lapangan 
dengan mengadakan penyelidikan secara langsung di lapangan untuk berbagai masalah yang ada relevansinya dengan penelitian ini.

Selain itu, penelitian ini juga termasuk dalam kategori penelitian pengembangan (development research), yaitu penelitian yang bermaksud menyelidiki pertumbuhan atau perubahan sesuatu sebagai fungsi waktu. Jadi penelitian ini merupakan penelitian yang sudah terlebih dahulu dilakukan penelitian hanya saja penelitian ini lebih kompleks dan berbeda pada obyek yang akan diteliti dan lokasi penelitian (Masyhuri dan M. Zainuddin, 2011).

Pendekatan pada penelitian ini menggunakan pendekatan studi kasus. Penelitian studi kasus (case study) adalah bentuk penelitian yang mendalam tentang suatu aspek lingkungan sosial termasuk manusia di dalamnya. Case study dapat dilakukan terhadap seorang individu, sekelompok individu (misalnya suatu keluarga), segolongan manusia, lingkungan hidup manusia (desa, sektor kota) atau lembaga sosial (S. Nasution, 2006).

\section{Hasil dan Pembahasan}

1. Latar belakang istri nelayan melakukan peran ganda di dalam rumah tangga

Masyarakat pesisir atau masyarakat nelayan di kampung pesisir Desa Betahwalang Kecamatan Bonang Kabupaten Demak merupakan salah satu komunitas sosial yang kelangsungan hidupnya bergantung pada kemampuannya dalam mengelola sumber daya perikanan laut yang tersedia di lingkungan sekitarnya. Karena pendapatan dari hasil melaut bersifat spekulatif dan tidak menentu, hal tersebut dapat sebabkan oleh cuaca maupun musim, dll. untuk memenuhi kebutuhan hidup sehari-hari para istri nelayan memegang peranan yang sangat penting. Sebagian besar istri nelayan di Desa Betahwalang memegang penuh dalam mengatur keuangan rumah tangganya. Istri yang akan mengatur sirkulasi ekonomi di dalam keluarga.

Hal tersebut akan menjadi problem apabila suami tidak mendapatkan hasil dari kegiatan melautnya. Otomastis istri yang memikirkan untuk mencari jalan keluar bagaimana bisa mencukupi kebutuhan seharihari. Kaum istri dapat melakukan pekerjaan apa saja yang sekiranya dapat mereka kerjakan. Berdasarkan pengamatan di lapangan, terdapat beberapa faktor yang melatarbelakangi kaum istri nelayan Desa Betahwalang melakukan peran publik (ikut mencari nafkah), di antaranya:

a. Faktor internal

Ada beberapa faktor internal yang menjadi latar belakang istri nelayan Kampug Rajungan Demak melakukan peran ganda, yaitu:

\section{1) Kemiskinan}

Menurut Pak Norjaya (45 tahun), tokoh masyarakat nelayan Desa Betahwalang, sudah menjadi hal umum apabila istri nelayan ikut bekerja dalam mencukupi kebutuhan ekonomi rumah tangganya.

"Pendapatan nelayan itu kan tidak menentu. Kalau sedang musim ikan bisa dapat banyak. Kalau lagi tidak musim ya dapatnya cuman dikit, belum lagi kalau cuacanya sedang tidak bagus. Otomatis nelayan juga tidak berani melaut, karena resikonya yang terlalu besar. Akibatnya ya tidak dapat penghasilan. Oleh karena itu ya istri saya mau tidak mau harus membantu saya untuk memenuhi kebutuhan hidup sehari-hari. Kan banyak pekerjaanpekerjaan yang bisa dilakukan oleh kaum istri, misalnya menjual ikan, membuat gereh (ikan asin), krupuk ikan, petis ikan, dll.

Pernyataan tersebut juga selaras dengan pernyataan Ibu Mubaidah (53 tahun)

"Saya membuat ikan asin juga utuk mencukupi kebutuhan sehari-hari. Kalau cuma bergantung dengan hasil tangkapan melaut 
suami saya ya tidak bisa mencukupi kebutuhan. Soalnya melaut kan hasilnya tidak menentu, kadang dapat banyak, kadang ya sedikit, kadang malah tidak dapat sama sekali.”

Pernyataan yang telah disebutkan sebelumnya, diperkuat dengan pernyataan yang disampaikan oleh Ibu Sulastri (55 tahun),

"Saya kerja untuk membantu suami mencari nafkah, karena pendapatan suami dari melaut itu tidak menentu. Kadang dapat banyak, kadang dikit, kadang tidak dapat sama sekali. Sekarang suami juga udah tua. Jadi ya tenaganya udah kurang kuat kayak dulu. Sekarang suami saya cuman jadi buruh di tambak. Melaut ya kadang-kadang itu juga kalo cuacanya pas. Jadinya saya ikut bekerja agar bisa memenuhi kebutuhan sehari-hari.”

Dari pernyataan tersebut dapat dianalisis bahwa kemiskinan merupakan faktor umum yang melatarbelakangi para istri nelayan ikut serta dalam mencari nafkah (berperan ganda) di dalam keluarga. Kebutuhan yang harus terpenuhi sedangkan alat pemenuh kebutuhan tidak selalu ada karena pendapatan suami yang bermata pencaharian sebagai nelayan bersifat spekulatif. Berangkat dari hal tersebut, para istri termotivasi untuk ikut serta dalam mencari nafkah tambahan sebagai penutup/penopang apabila pendapatan suami tidak cukup untuk memenuhi kebutuhan.

\section{2) Mengoptimalkan waktu luang}

Beberapa kaum istri memilih bekerja untuk memanfaatkan waktunya. Bagi sebagian istri berasumsi daripada waktunya tidak produktif, lebih baik digunakan untuk bekerja, selain bisa memanfaatkan waktu agar lebih maksimal dan bisa membantu meringankan beban suaminya.

Dari pernyataan yang di ungkapkan oleh Ibu Anituz Zaroah (34 tahun), beliau menuturkan,
"Saya kerja untuk mengisi waktu luang, Dari pada nganggur tidak ada kegiatan apa-apa, ada kesempatan juga buat kerja ya saya ambil saja. Suami juga mengijinkan dan untuk membantu suami juga, karena pendapatan melaut saat ini yang tidak menentu, kadang dapat banyak, kadang dikit, kadang tidak dapat sama sekali. Dan untuk mencukupi kebutuhan sehari-hari, biaya sekolah anak juga.”

Sebagian istri nelayan bekerja hanya untuk mencari tambahan penghasilan di mana yang tidak terlalu mengikat dan cenderung santai, sehingga mereka dapat mengatur peranannya baik dalam bekerja (sektor publik) maupun tanggung jawabnya sebagai ibu dan istri di dalam rumah tangga. Pernyataan tersebut juga diperkuat sesuai pendapat Ibu Kasturah (45 tahun),

"Saya bekerja untuk mengisi waktu luang dan membantu suami memenuhi kebutuhan sehari-hari, karena jika hanya mengandalkan hasil melaut tidak cukup."

Pernyataan tersebut dapat dianalisis bahwa faktor internal yang melatarbelakangi istri nelyan ikut andil dalam mencari nafkah selain faktor ekonomi yaitu untuk mengoptimalkan waktu luang. Agar waktu yang dimiliki lebih optimal para istri nelayan memanfaatkannya dengan bekerja sehingga waktu yang dimiliki lebih produktif. Pekerjaan-pekerjaan yang dilakukan pun tergolong pekerjaan yang mudah dikerjakan. Selain itu pekerjaan rumah dapat dikerjakan setelah ataupun sebelum melakukan pekerjaan di luar dan tidak mengganggu peranannya di dalam rumah tangga.

\section{b. Faktor eksternal}

Dari pengamatan yang dilakukan oleh penulis, faktor eksternal yang melatarbelakangi istri nelayan Kampung Rajungan Demak ikut serta dalam sektor publik yaitu tersedianya lapangan pekerjaan. Potensi alam Desa Betahwalang yang melimpah memberikan 
kontribusi dalam bidang ekonomi salah satunya membuka lapangan-lapangan pekerjaan untuk para masyarakatnya. Di Desa Betahwalang sebagian kaum istri bekerja menjadi buruh pengupas rajungan dan perajut bubu lipat. $\mathrm{Hal}$ ini menunjukkan bahwa kegiatan ekonomi perikanan di Desa Betahwalang juga memberikan peluang kerja bagi penduduknya khususnya para kaum istri.

Hasil wawancara dengan Ibu Wanadiroh (30 tahun) menyatakan,

“...Saya juga ikut bekerja untuk memenuhi kebutuhan sehari-hari. Ya ada kesempatan juga, ada yang nawari kerja ya saya ambil. Kalau cuma bergantung sama suami ya tidak cukup”.

Pernyataan tersebut juga selaras dengan yang disampaikan Ibu Sudarsih (38 tahun),

“...Daripada nggak ngapa-ngapain, ada kesempatan juga ya saya ambil. Lumayan bisa digunakan buat beli kebutuhan sehari-hari, buat jajan anak, belanja. Kan hasil suami melaut tidak menentu juga."

Dari pernyataan di atas, penulis dapat menganalisa sebagian istri nelayan Desa Betahwalang yang memilih untuk bekerja disebabkan adanya peluang kerja yang tersedia. Di samping untuk memanfaatkan waktu dan peluang, kaum istri yang bekerja juga dapat memberikan pengaruh pada perekonomian keluarga. Pendapatan suami yang tidak menentu (spekulatif) memaksa kaum istri untuk memutar otak agar kebutuhan sehari-hari dapat terpenuhi terlebih lagi apabila suami tidak mendapatkan penghasilan dari kegiatan melaut. Oleh sebab itu, adanya peluang kerja yang tersedia menjadi solusi bagi kaum istri untuk meningkatkan taraf perekonomian keluarga agar kebutuhan seharihari dapat terpenuhi.

2. Upaya konvergensi yang dilakukan istri nelayan dalam penguatan ekonomi rumah tangga
Pada hakikatnya, di dalam keluarga istri hanya berkewajiban menjaga dan mengatur rumah tangga suaminya. Di dalam masyarakat Islam, yang bertanggung jawab dan berkewajiban mencari nafkah adalah suami. Istri hanya berkewajiban mengurus dan bertanggungjawab atas rumah tangga suaminya. Dengan begitu istri yang akan mengurus segala urusan di dalam rumah tangga salah satunya mengatur sirkulasi keuangan rumah tangga.

Keadaan tersebut akan berkembang bila mana seorang istri ikut andil dalam mencari nafkah. Hal tersebut pasti tidak dilakukan bukan tanpa sebab, seperti karena tuntutan keadaan ekonomi yang mengharuskan istri ikut serta dalam mencari nafkah. Dengan kata lain karena kemiskinan, keinginan untuk membantu suami, mengisi waktu luang, tersedianya lapangan pekerjaan, dan lain sebagainya.

Di Desa Betahwalang para istri nelayan melakukan upaya yang berbeda-beda dalam usaha menguatkan taraf ekonomi rumah tangganya. Dari hasil penelitian upaya-upaya konvergensi yang dilakukan istri nelayan dalam penguatan ekonomi rumah tangga di antaranya:

a. Wirausaha

Wirausaha merupakan orang yang menciptakan sebuah bisnis yang berhadapan dengan risiko dan ketidakpastian, bertujuan memperoleh profit dan mengalami pertumbuhan dengan cara mengidentifikasi kesempatan dan memanfaatkan sumber daya yang diperlukan.

Berwirausaha menjadi salah satu pilihan istri yang mengemban peran ganda di dalam rumah tangga. Karena wirausaha dapat dilakukan sesuai dengan keinginan sendiri (tidak terikat seperti halnya buruh). Seorang wirausahawan dapat melakukan apapun yang ia mau tanpa ada yang menyuruh. Dalam hal ini, seorang istri yang melakukan peran ganda dengan berwirausaha dapat mengatur waktunya 
sendiri antara perannya di rumah tangga (domestik) maupun publik.

Di Desa Betahwalang ada beberapa macam kegiatan wirausaha yang dilakukan oleh para istri nelayan, diantaranya yaitu sebagai pembuat ikan asin, pembuat rempeyek udang, dan penjual jajanan anak-anak. Dengan berwirausaha, istri dapat menopang pendapatan suami yang bekerja sebagai seorang nelayan yang memiliki pendapatan yang tidak bisa dipastikan (spekulatif). Apabila suami tidak mendapatkan hasil dari pergi melaut, maka pendapatan istri dapat meng-cover pendapatan suami untuk mencukupi kebutuhan sehari-hari misalnya untuk belanja kebutuhan pangan, uang saku anak, uang jajan anak, dll.

Sesuai dengan pernyataan yang disampaikan oleh Ibu Dariyah (54 tahun),

"Saya kerja untuk membantu suami mencari nafkah, karena pendapatan suami dari melaut itu tidak menentu. Kadang dapat banyak, kadang dikit, kadang tidak dapat sama sekali. Jadinya saya ikut bekerja agar bisa memenuhi kebutuhan sehari-hari.”

Dalam upaya menguatkan ekonomi rumah tangganya, Ibu Dariyah membuat ikan asin dari ikan hasil tangkapan suaminya yang tidak laku dijual. Apabila ikan hasil tangkapan suaminya laku terjual semua, Ibu Dariyah tidak memproduksi ikan asin. Jadi, Ibu Dariyah memproduksi hanya mengandalkan ikan hasil tangkapan melaut yang tidak laku dijual. Ibu Dariyah menjual ikan asin dengan harga 25.000 hingga 30.000 tergantung pada kualitas dan jenis ikannya.

"Usaha saya dengan membuat ikan asin terus bisa dijual, dan hasilnya buat tambahtambah pendapatan suami saya, buat belanja kebutuhan sehari-hari."

Selain pembuat ikan asin, di Betahwalah istri nelayan yang berwirausaha dalam menguatkan ekonomi rumah tangga juga berprofesi sebagai pembuat rempeyek udang, seperti yang dilakukan oleh Ibu Sulastri (55 tahun). Dalam kesehariannya Ibu Sulastri membuat rempeyek udang untuk dijual di pasar pagi di Desa Betahwalang.

"Upaya yang bisa saya lakukan ya membuat rempeyek udang, terus saya jual di pasar."

Dari hasil membuat dan menjual rempeyek udang, Ibu Sulastri setiap hari memperoleh pendapatan 75.000 sampai 150.000. Apabila sedang ramai Ibu Sulastri dapat memperoleh penghasilan 150.000 sehari. Namun, hasil tersebut masih kepotong biaya produksi atau belum pendapatan bersih, dan keuntungannya untuk mencukupi kebutuhan sehari-hari.

"Kalau lagi rame bisa sampai 150 ribu, kadang juga 120 ribu, kadang 100 ribu. Kalau lagi sepi dapatnya 75 ribu sampai 80 ribu. Tapi itu juga masih buat beli bahan-bahan lagi, belum bersih."

Bentuk usaha lain yang dilakukan istri nelayan di Desa Betahwalang yaitu sebagai penjual jajanan anak-anak seperti yang dilakukan oleh Ibu Kasturah. Untuk menguatkan ekonomi rumah tangganya Ibu Kasturah menjual jajanan anak-anak di dekat sekolah SD. Usaha tersebut dimaksudkan untuk menambah pendapatan rumah tangga yang akan digunakan untuk mencukupi kebutuhan sehari-hari.

"Upaya saya berjualan jajanan anak-anak di SD dekat rumah, dengan hasil jualan ini bisa saya gunakan untuk memenuhi kebutuhan sehari-hari."

Dari upaya-upaya yang dilakukan istri nelayan dalam menguatkan ekonomi rumah tangga dengan cara bisnis, mereka melakukan wirausaha sesuai dengan apa yang dapat mereka kerjakan dan sesuai dengan kemampuan mereka. Seperti berjualan, ataupun membuat produk olahan ikan misalnya ikan asin dan rempeyek 
udang. Upaya-upaya tersebut dilakukan istri nelayan dengan harapan agar kebutuhan rumah tangga dapat terpenuhi. Sehingga ekonomi rumah tangga menjadi semakin kuat.

\section{b. Menjadi buruh}

Selain berwirausaha istri-istri nelayan yang melakukan peran ganda memilih profesi sebagai buruh. Menjadi buruh merupakan pilihan yang dapat diambil apabila seseorang tidak memiliki modal untuk berwirausaha. Baik modal materi maupun modal keahlian (skill).

Potensi alam yang cukup besar khususnya kekayaan laut memberi dampak tersendiri bagi masyarakat Desa Betahwalang. Salah satunya yaitu membuka lapangan pekerjaan bagi masyarakatnya. Para pengusaha yang usahanya sudah cukup besar tentu akan menyerap tenagatenaga kerja khususnya para kaum wanita untuk proses produksinya. Hal ini memberikan dampak postif bagi kaum istri nelayan yang ingin memperoleh penghasilan tambahan untuk membantu meringankan beban suaminya. Pekerjaan-pekerjaan yang dilakukan oleh istri nelayan yang menjadi buruh tergolong pekerjaan yang ringan dan mudah untuk dikerjakan. Selain itu juga tidak terlalu mengikat seperti buruh di perusahaan-perusahaan besar.

Sebagian istri nelayan di Desa Betahwalang bekerja menjadi buruh pengupas rajungan dan buruh pengrajut jebak rajungan (bubu lipat). Salah satu istri nelayan yang bekerja menjadi buruh pengupas rajungan adalah Ibu Sudarsih, dan salah satu istri yang menjadi buruh pengrajut jebak rajungan yaitu Ibu Sutriyah. Hasil wawancara dengan Ibu Sudarsih (38 tahun) beliau menuturkan,

"Saya bekerja menjadi buruh pengupas rajungan di miniplant. Ya meskipun hasilnya tidak banyak tapi lumayan pendapatannya bisa untuk membantu keuangan keluarga, bisa buat tambah-tambah buat kebutuhan sehari-hari.”
Ibu Sudarsih bekerja menjadi buruh pengupas rajungan di miniplant milik salah satu pengusaha di Desa Betahwalang. Dalam sehari beliau dapat memperoleh pengahsilan 40.000 hingga 50.000 perhari. Hasil tersebut naik turun tergantung pada kuantitas dan kualitas dari rajungannya sediri. Apabila jurangannya dapat banyak rajungan dengan kualitas super, otomatis pendapatan yang dihasilkan oleh para buruh pengupasnya juga akan naik (tinggi).

"Pendapatan yang saya dapat sekitar 40-50 ribu per harinya tergantung banyaknya barang dan kualitas rajungannya. Kalo rajungannya bagus, bossnya jualnya juga mahal, nanti upahnya juga dikasih bonus."

Selain Ibu Sudarsih, Ibu Sutriyah (54 tahun) juga bekerja sebagai buruh. Akan tetapi bukan buruh pengupas rajungan, namun sebagai buruh pengrajut bubu lipat. Dari hasil wawancara beliau menuturkan,

"Setiap hari saya membuat jebak rajungan (bubu lipat), lumayan mas buat tambah-tambah beli beras."

Selain Ibu Sutriyah, istri nelayan yang bekerja sebagai buruh pengrajut jebak rajungan (bubu lipat) ada Ibu Sularsih (50 tahun) dan Siti Baekah (50 tahun). Rata-rata para ibu-ibu pengrajut bubu lipat dapat menghasilkan 10 hingga 12 jebak dan perjebaknya memdapat upah 1.800 sesuai dengan hasil wawancara dengan Ibu Sularsih (50 tahun),

"Biasanya sehari bisa buat 10-12 jebak, satunya dihargai $R p 1.800$ ya sekitar 15 ribu sampai 20 ribuan seharinya."

Pernyataan tesebut selaras dengan yang disampaikan Ibu Sutriyah (52 tahun),

"Perharinya kadang dapat 15ribu25ribuan, tergantung banyaknya jebak yag dibuat, satu jebak upahnya 1800. Ya rata-rata dapat 10-12 jebak. Kalau dibantu suami saya ya bisa nyampek 15 jebak lebih.” 
Dari pernyataan-pernyataan di atas, penulis dapat menganalisa istri nelayan di Desa Betahwalang yang berperan ganda sebagai buruh terdiri atas buruh pengupas rajungan dan buruh pengrajut jebak rajungan (bubu lipat). Profesi tersebut diambil oleh para istri nelayan karena pekerjaan yang dilakukan pun tergolong ringan, dan waktunya tidak terlalu mengganggu peranannya di dalam keluarga. Para istri yang menjadi buruh pengupas rajungan, mereka bekerja saat juragannya sudah memperoleh rajungan dari para nelayan dan waktunya juga tidak pasti. Sedangkan para istri yang berperan ganda sebagai buruh pengrajut jebak rajungan (bubu lipat) mereka bekerja pada saat semua urusan rumah tangga telah elesai dikerjakan. Mereka mengambil bahan-bahan dari juragan/pengepul dan dibawa pulang. Para istri mengerjakannya di rumah dan disetor kepada juragannya apabila telah jadi.

Dari semua istri yang berperan ganda di dalam keluarga tentu telah mendapat ijin dari suami. Peran tersebut mereka lakukan dengan tujuan agar kebutuhan sehari-hari dapat terpenuhi. Apabila kebutuhan dapat terpenuhi dengan baik, maka perekonomian rumah tangga pasti semakin kuat dan semakin baik.

3. Kontribusi istri nelayan dalam menguatkan ekonomi rumah tangga

Menurut Kamus Besar Bahasa Indonesia, kontribusi diartikan sebagai uang iuran (kepada perkumpulan dan sebagainya) atau sumbangan (https://kbbi.kemdikbud.go.id/entri/kontribusi. diakses 2019). Secara umum, kontribusi dapat diartikan sebagai peran kita keikutsertaan terhadap sesuatu. Selain itu kontribusi juga dapat diartikan sebagai keikutsertaan, melibatkan diri, atau memberi sumbangan (baik berupa materi, tenaga, ataupun pikiran).

Dari hasil wawancara penulis kepada istri nelayan yang melakukan peran ganda di dalam keluarga tentang signifikasi kontribusi istri nelayan dalam menguatkan ekonomi rumah tangga yaitu dengan Ibu Sulastri (55 tahun) beliau menuturkan,

"Dari hasil saya kerja, penghasilan dari jualan rempenyek alhamdulillah bisa bantu suami. Soalnya pendapatan suami tidak menentu. Saya sebagai istri yang ngatur dan megang uang secara penuh ya harus bisa mengaturnya dengan baik. namun kalau mengambil keputusan saya selalu musyawarah sama suami."

Penghasilan yang diperoleh Ibu sulastri dari hasil jualan rempeyek udang dapat memberikan kontribusi terhadap ekonomi rumah tangganya. Penghasilan Ibu Sulastri dapat membantu pendapatan suami apabila suaminya mendapatkan hasil yang tidak dapat untuk mencukupi kebutuhan. Di sini, penghasilan Ibu Sulastri berperan sebagai penyangga pendapatan suami yang spekulatif.

Pernyataan tersebut selaras dengan yang disampaikan oleh Ibu Sudarsih (38 tahun), beliau menuturkan,

"Dengan saya bekerja, saya bisa mendapat penghasilan. Jadi bisa buat bantu memenuhi kebutuhan rumah tangga. Kalau hanya mengandalkan penghasilan suami ya rada susah buat menuhi kebutuhan rumah tangga. Hasilnya kan tidak menentu.”

Kontribusi istri nelayan di Desa Betahwang tidak terbatas pada penghasilan yang dapat menyangga pendapatan suami apabila tidak mencukupi kebutuhan. Namun sebagian besar keluarga nelayan di Desa Betahwalang, seorang istri juga bertanggung jawab sebagai pengatur penuh perekonomian keluarga. Seperti yang telah disampaikan oleh Ibu Sulastri pada kutipan sebelumnya,

“...Saya sebagai istri yang ngatur dan megang uang secara penuh ya harus bisa mengaturnya dengan baik. namun kalau mengambil keputusan saya selalu musyawarah sama suami." 
Pernyataan tersebut selaras dengan pernyataan yang disampaikan Ibu Mubaidah, beliau menuturkan,

"Istri kan biasanya kalau di rumah kan yang pegang uang, ngatur uang. Jadi saya sebagai istri memang harus pintar-pintar mengatur dan menggunakannya."

Di dalam keluarga nelayan sudah menjadi kebiasaan bahwa seorang istri lah yang menjadi pemegang dan pengatur penuh keuangan rumah tangga. Istri yang mengelola segala pengeluaran dan mengalokasikan dana agar kebutuhan rumah tangga dapat tercukupi dan tidak terjadi ketimpangan dalam ekonomi rumah tangga.

Kontribusi istri dapat dikatakan sebagai katup pengaman (safety valve) atau penopang bagi rumah tangga yang tingkat perekonomiannya rendah untuk memenuhi kebutuhan sehari-hari. Dengan adanya upaya para istri nelayan berperan ganda memberikan dampak positif bagi ekonomi rumah tangga. Pendapatan yang didapatkan istri akan menambah pendapatan keluarga yang awalnya hanya bergantung pada pendapatan suami. Dengan adanya tambahan pendapatan dari istri yang meningkatkan pendapatan rumah tangga otomatis tingkat pemenuhan kebutuhan rumah tangga juga akan meningkat. Dalam hal ini ekonomi rumah tangga dapat dikatakan membaik sehingga terjadi penguatan ekonomi rumah tangga.

Dari pernyataan tersebut di atas, dapat diketahui bahwa peranan istri di dalam rumah tangga sangat penting. Hal tersebut ditunjukkan bahwa istri yang mengatur segala urusan rumah tangga termasuk perihal keuangan serta kontribusi pendapatan istri yang dapat meningkatkan pendapatan rumah tangga. Dengan kata lain, peranan istri di dalam rumah tangga memberikan kontribusi yang signifikan dalam penguatan ekonomi rumah tangga.
Penutup

Berdasarkan analisis dan pembahasan dari data peran ganda istri nelayan dalam penguatan ekonomi rumah tangga, maka dapat ditarik kesimpulan sebagai berikut:

1. Faktor yang melatarbelakangi istri nelayan Kampung Rajungan berperan ganda di dalam keluarga dibedakan atas pertama faktor internal meliputi faktor ekonomi (kemiskinan) dan faktor keinginan untuk mengoptimalkan waktu luang, kedua faktor eksternal meliputi tersedianya lapangan pekerjaan.

2. Upaya konvergensi yang dilakukan istri nelayan dalam penguatan ekonomi rumah tangga diantaranya pertama dengan berwirausaha meliputi bekerja sebagai penjual, pembuat ikan asin, dan penjual rempeyek udang, kedua bekerja sebagai buruh meliputi buruh pengupas rajungan dan pengrajut jebak rajungan (bubu lipat).

Kontribusi istri nelayan dalam menguatkan ekonomi rumah tangga memberikan kontribusi yang signifikan. Kontribusi istri dapat dikatakan sebagai katup pengaman (safety valve) atau penopang bagi rumah tangga yang tingkat perekonomiannya rendah untuk memenuhi kebutuhan sehari-hari apabila pendapatan suami tidak mencukupi.

\section{Daftar Pustaka}

"Negara Maritim.” Binus University. 2/03/2019, http://scdc.binus.ac.id/himpgsd/2017/09/ negara-maritim/.

"Pentingnya Informasi Geopasial Untuk Menata Laut Indonesia." Badan Informasi Geospasial. - 19/12/2018, http://big.go.id/beritasurta/show/pentingnya-informasigeospasial-untuk-menata-laut-indonesia/. 
"The State of World Fisheries and Aquaculture 2012." FAO Fisheries and Aquaculture Department of The United Nations. 19/12/2018, http://www.fao.org/3/ai2727e.pdf/.

Arsini. "Peran Ganda Perempuan Pada Keluarga Masyarakat Agraris: Kasus 10 Istri Buruh Tani di Desa Putat Purwodadi Grobogan.” Jurnal Sawwa 10, no. 1 (2014): 1-20.

Azwar, Saifuddin. Metode Penelitian. Yogyakarta: Pustaka Pelajar Offset, 2004.

Djuwita, Diana. "Peran Perempuan Masyarakat Pesisir dalam Meningkatkan Pendapatan Keluarga nelayan di Desa Mertasinga," Jurnal Al-Amwal 7, no. 2 (2015): 144155.

Doriza, Shinta. Ekonomi Keluarga. Bandung: Remaja Rosda Karya, 2015.

H., Ferdhi. "Kontribusi Istri Nelayan Terhadap Pendapatan Keluarga di Desa Langgapulu Kecamatan Kolono Timur Kabupaten Konawe Selatan.” Skripsi, Universitas Halu Oleo Kendari, 2006.

Handayani dan Endang Gunaisah, "Kajian Perempuan Dalam Mendukung Konservasi Sumber Daya Pesisir di Kabupaten Raja Ampat," Jurnal Airaha 1, no. 1 (2012): 1-12.

Hardinsyah dan Ujang Sumarwan. "Pemberdayaan Ekonomi Keluarga." Presentasi pada Seminar Nasional IPADI, Bogor, 25-26 November 1997.

Hasbiallah, Keluarga Sakinah. Bandung: PT Remaja Rosdakarya, 2015.

Hikmat, Harry. Strategi Pemberdayaan Masyarakat. Bandung: Humaniora, 2004.

Imron, Masyhuri. "Kemiskinan Dalam Masyarakat Nelayan.” Jurnal Masyarakat dan Budaya 5, no. 1 (2003): 63-82.

KBBI Daring, diakses dari https://kbbi.kemdikbud.go.id/entri/kontri busi.

Kuncoro, Mudrajad. Ekonomika Pembangunan: Teori, Masalah dan Kebijakan, Edisi
Keempat. Yogyakarta: UPP STIM YKPN, 2006.

Kusnadi, Hari Sulistiyowati, Sumarjono, Adi Prasodjo. Perempuan Pesisir. Yogyakarta: LKIS Pelangi Aksara, 2006.

Kusnadi. Konflik Sosial Nelayan: Kemiskinan Dan Perebutan Sumberdaya Perikanan. Yogyakarta: LKIS, 2002.

Kusnadi. Pemberdayaan Perempuan Pesisir: Pengembangan Sosial-Ekonomi Masyarakat Pesisir Melalui Budidaya Rumput Laut. Yogyakarta: Graha Ilmu, 2015.

Marzuki. "Studi Tentang Kesetaraan Gender Dalam Berbagai Aspek." Presentasi pada Sosialisasi Kesetaraan Gender Kegiatan KKN Universitas Negeri Yogyakarta di PKBM Sekar Melati, Sleman, 24 Desember, 2008.

Masyhuri dan M. Zainuddin. Metode Penelitian Pendekatan Praktis dan Aplikatif. Bandung: Refia Aditama, 2011.

Mirna. "Partisipasi Istri Nelayan Dalam Membantu Ekonomi Keluarga di Kelurahan Bontang Kuala Kecamatan Bontang Utara Kota Bontang." Jurnal Sosiatri-Sosiologi 4, no. 3 (2016): 113126.

Mulyanto, Dede. Usaha Kecil dan Persoalan Di Indonesia. Bandung: Yayasan AKATIGA, 2006.

Nugroho, Rian. Gender dan Administrasi Publik. Yogyakarta: Pustaka Pelajar, 2008.

Nurholis, Ahmad. "Partisipasi Istri Nelayan Dalam Pemanfaatan Sumberdaya Pesisir (Studi Tentang Strategi Pengentasan Kemiskinan Keluarga Nelayan Desa Margasari Kecamatan Labuhan Maringgai Kabupaten Lampung Timur).” Skripsi, Universitas Lampung, 2016.

Nurwati, Nunung. "Kemiskinan : Model Pengukuran, Permasalahan dan Alternatif Kebijakan.” Jurnal Kependudukan Padjadjaran 10, no. 1, (2008): 1-11. 
Jurnal Harkat : Media Komunikasi Gender, 15 (1), 2019

PERMARI, “3 Tahun 2017, Pedoman Mengadili Perkara Perempuan Berhadapan Dengan Hukum," (11 Juli 2017).

Puspitasari, Dewi Cahyani. "Modal Sosial Perempuan dalam Peran Penguatan Ekonomi Keluarga." Jurnal Pemikiran Sosiologi 1, no. 2, (2012): 69-80.
Soerjono. Sosiologi: Suatu Pengantar. Jakarta: Rajagrafindo Persada, 1997.

Sugiyono. Metode Penelitian Kuantitatif, Kualitatif, dan R\&D. Bandung: Alfabeta, 2011. 